\title{
FLOOD MAGNITUDE AND FREQUENCY OF BLACK CREEK TRIBUTARY AT THE CULVERT ON NEW JERSEY ROUTE 94 IN VERNON TOWNSHIP, SUSSEX COUNTY, NEW JERSEY
}

U.S. GEOLOGICAL SURVEY

Open-File Report 96-324

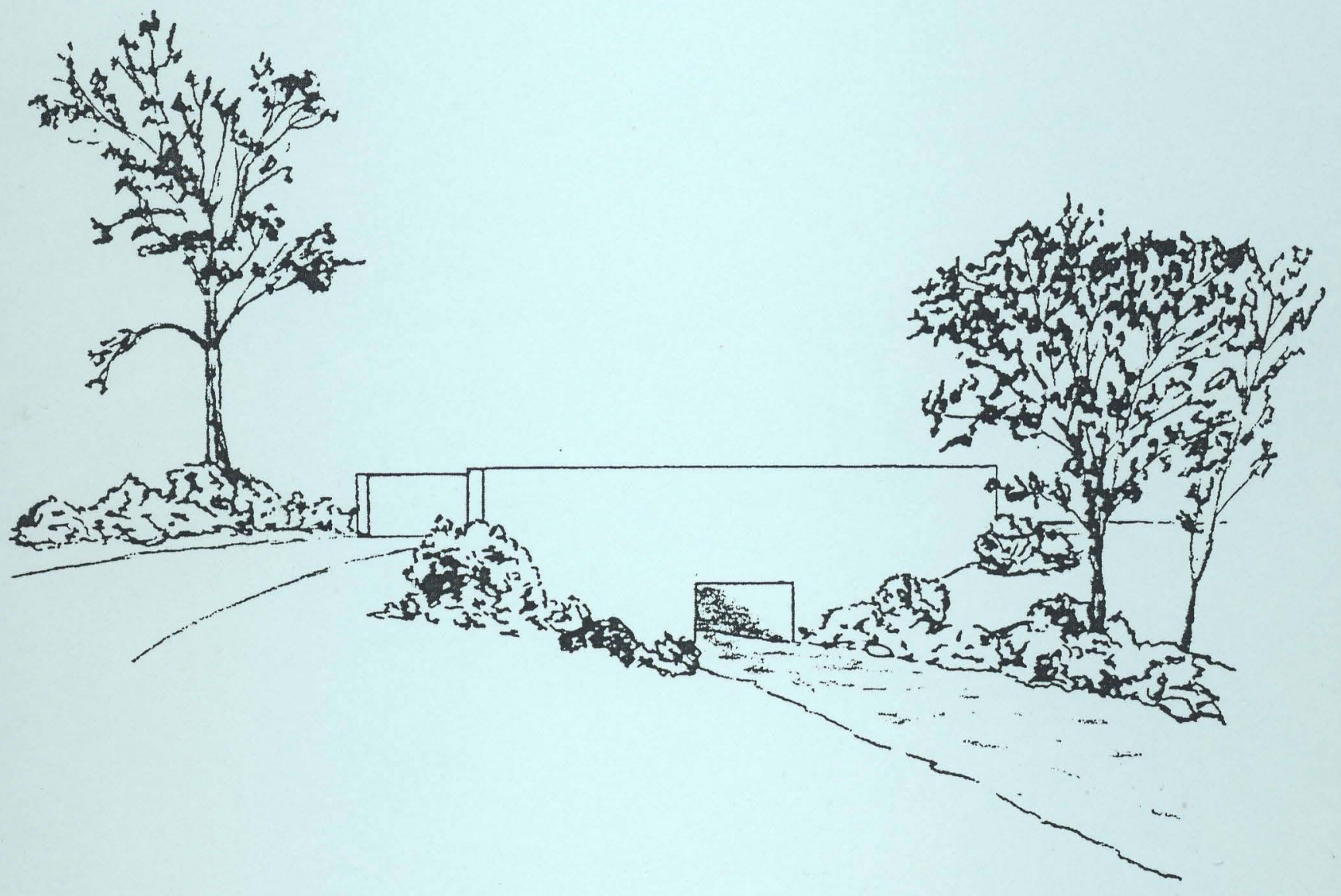

Prepared in cooperation with the NEW JERSEY DEPARTMENT OF TRANSPORTATION

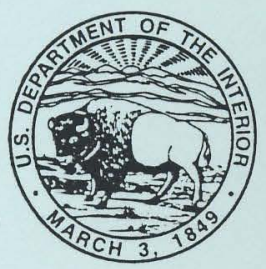


FLOOD MAGNITUDE AND FREQUENCY OF BLACK CREEK TRIBUTARY AT THE CULVERT ON NEW JERSEY ROUTE 94 IN VERNON TOWNSHIP, SUSSEX COUNTY, NEW JERSEY

By Thomas Barringer

U.S. GEOLOGICAL SURVEY

Open-File Report 96-324

Prepared in cooperation with the

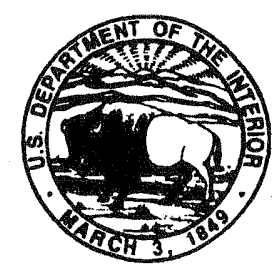
NEW JERSEY DEPARTMENT OF TRANSPORTATION

West Trenton, New Jersey 1996 


\title{
U.S. DEPARTMENT OF THE INTERIOR
}

\author{
BRUCE BABBIT, Secretary
}

U.S. GEOLOGICAL SURVEY

Gordon P. Eaton, Director

For additional information write to:

District Chief

U.S Geological Survey

Mountain View Office Park

810 Bear Tavern Road, Suite 206

West Trenton, NJ 08628
Copies of this report can be obtained from:

U.S Geological Survey

Earth Science Information Center

Open-File Reports Section

Box 25286, MS 517

Denver Federal Center

Denver, CO 80225 


\section{CONTENTS}

Page

Abstract.

Introduction

1

Methods for determining flood magnitude and frequency ............................................................

New Jersey Department of Environmental Protection Special Report 38 method....................................... 3

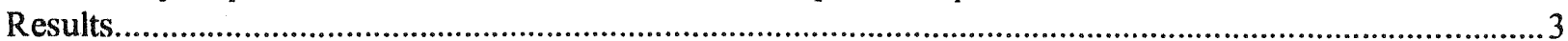

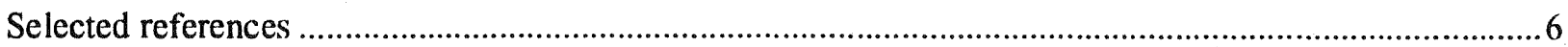

\section{ILLUSTRATIONS}

Figure 1. Map showing location of Black Creek tributary at the culvert at milepost 43.0 on New Jersey Route 94 and associated drainage basin, Vernon Township, New Jersey ....

\section{TABLES}

Table 1. Explanatory variables for the flood-magnitude and -frequency analysis of Black Creek tributary at the culvert on New Jersey Route 94, milepost 43.0, Vernon Township, New Jersey ..............................................................................................................................

2. Estimates of flood magnitudes for selected flood frequencies for Black Creek tributary at the culvert on New Jersey Route 94, milepost 43.0, Vernon Township, New Jersey ................5 


\section{CONVERSION FACTORS}

$\begin{array}{lll}\text { Multiply } & \text { By } & \text { To obtain } \\ \text { foot }(\mathrm{ft}) & 0.3048 & \text { meter } \\ \text { mile }(\mathrm{mi}) & 1.609 & \text { kilometer } \\ \text { square mile }\left(\mathrm{mi}^{2}\right) & 2.590 & \text { square kilometer } \\ \text { foot per mile }(\mathrm{ft} / \mathrm{mi}) & 0.189 & \text { meter per kilometer } \\ \text { cubic foot per second }\left(\mathrm{ft}^{3} / \mathrm{s}\right) & 0.0283 & \text { cubic meter per second }\end{array}$




\title{
FLOOD MAGNITUDE AND FREQUENCY OF BLACK CREEK TRIBUTARY AT THE CULVERT ON NEW JERSEY ROUTE 94 IN VERNON TOWNSHIP, SUSSEX COUNTY, NEW JERSEY
}

\author{
By Thomas Barringer
}

\begin{abstract}
The magnitude and frequency of floods at Black Creek tributary at the culvert on New Jersey Route 94 at milepost 43.0 in Vernon Township, New Jersey, were determined by using the New Jersey Department of Environmental Protection Special Report 38 method. Estimates of flood magnitude and frequency calculated by the Special Report 38 method, as well as drainage-basin characteristics, are included in this report. The 100 -year-flood estimate is 261 cubic feet per second.
\end{abstract}

\section{INTRODUCTION}

Information on the magnitude and frequency of floods is critical to the planning and design of highway culverts and bridges. Such information is not readily available for many stream crossings in New Jersey. To fulfill this information need, the U.S. Geological Survey (USGS), in cooperation with the New Jersey Department of Transportation, began an analysis of flood data from stream-crossing sites on New Jersey streams.

This report presents results of the analysis for Black Creek tributary at the culvert on New Jersey Route 94 at milepost 43.0 in Vernon Township, New Jersey. The culvert is located at the intersection of New Jersey Route 94 and the road to Maple Grange (fig. 1). The drainage area upstream from the site is $0.60 \mathrm{mi}^{2}$. A field reconnaissance was performed on May 25,1995 , to verify the locations of the drainagebasin divides and basin characteristics. Because most of the northern part of the site is heavily wooded, steep, and has no road access, the calculated drainage area is approximate.

The flood insurance study for Vernon Township (Federal Emergency Management Agency, 1983) does not include a study of this stream. Therefore, flood discharges were not determined previously.

\section{METHODS FOR DETERMINING FLOOD MAGNITUDE AND FREQUENCY}

Various widely used methods for calculating flood magnitude and frequency were considered for use in determining the flood magnitudes that are likely to be exceeded at this site within a given number of years (recurrence interval). The rational method (Chow and others, 1988), New Jersey Department of Environmental Protection (NJDEP) Special Report 38 method (SR38) (Stankowski, 1974), the U.S. Soil Conservation Service (SCS) Technical Release 55 (TR-55) method (U.S. Soil Conservation Service, 1986), the USGS transfer method (New Jersey Department of Environmental Protection, 1988), and the index-flood method (Thomas, 1964) were all considered for use in determining flood magnitude and frequency of Black Creek tributary at the culvert on New Jersey Route 94, in Vernon Township, New Jersey. 

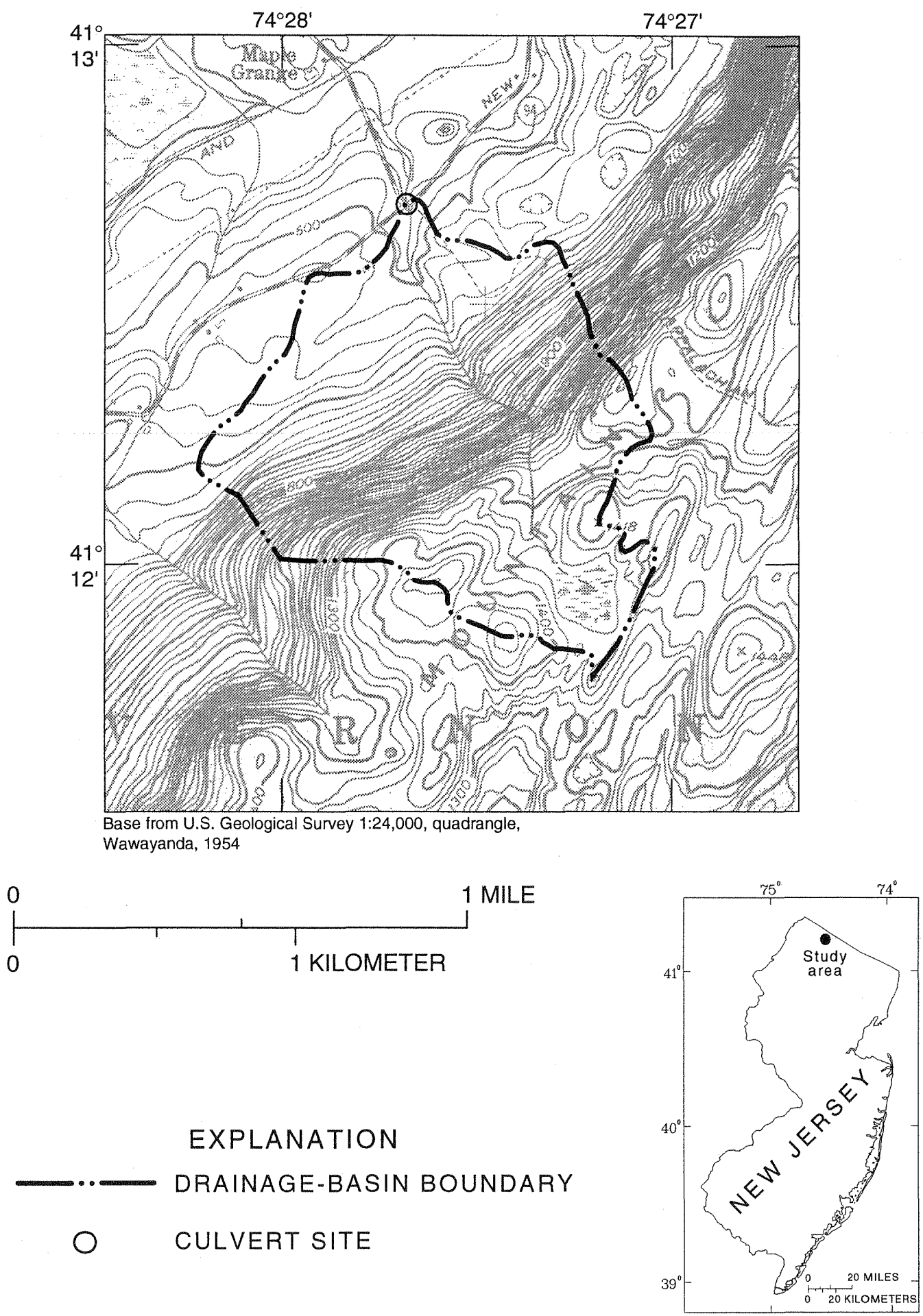

Figure 1. Location of Black Creek tributary at the culvert at milepost 43.0 on New Jersey Route 94 and associated drainage basin, Vernon Township, New Jersey. 


\section{NEW JERSEY DEPARTMENT OF ENVIRONMENTAL PROTECTION SPECIAL REPORT 38 METHOD}

The Special Report 38 method (Stankowski, 1974) is suitable for the estimation of flood magnitudes at sites located in drainage-basin areas greater than $1 \mathrm{mi}^{2}$. The area of the subject basin is $0.60 \mathrm{mi}^{2}$; however, it is sufficiently close to the minimum area to be acceptable.

Flood data from four streamflow gages located in drainage basins with characteristics similar to those of the subject basin and within a 49-mi radius of the culvert site were examined to determine whether the Special Report 38 method provides reasonable estimates of flood magnitude. These data were used to compute the USGS transfer-method estimates.

The average estimate of the 100-year flood made by using the USGS transfer method with streamflow data from four stations (Furnace Brook at Oxford, New Jersey, 01445490; Pequest River at Huntsville, New Jersey, 01445000; Mulhockaway Creek at Van Syckel, New Jersey, 01396660; and Quaker Creek, at Florida, New York, 01369500) was 0.85 times that of the SR38 estimate. The SR38 estimate was chosen because it agreed closely with the average transfer-method estimate.

\section{RESULTS}

Flood data from nearby streamflow or crest-stage gaging stations provide a good indication of the flood magnitude and frequency that can be expected at an ungaged site, particularly when drainage area and other basin characteristics are similar. In this study, estimates obtained by using the New Jersey Department of Environmental Protection Special Report 38 method agreed closely with estimates made by using the USGS transfer method.

The explanatory variables used in applying the USGS transfer method are listed in table 1 . The flood-magnitude and -frequency estimates made by using the SR 38 method are shown in table 2 . The estimate of the 100-year flood discharge at the culvert site is $261 \mathrm{ft}^{3} / \mathrm{s}$. 
Table 1. Explanatory variables for the flood-magnitude and -frequency analysis of Black Creek tributary at the culvert on New Jersey Route 94, milepost 43.0, Vernon Township, New Jersey

Drainage area: 0.60 square miles

Latitude: $41^{\circ} 12^{\prime} 42^{\prime \prime}$

Longitude: $74^{\circ} 27^{\prime} 42^{\prime \prime}$

Highway: New Jersey 94

Milepost: 43.00

U.S. Geological Survey 7-1/2-minute quadrangle: Wawayanda, N.J.-N.Y.

\begin{tabular}{llcl}
\hline \multicolumn{1}{c}{ Variable } & & Value & \multicolumn{1}{c}{ Unit } \\
\hline Drainage area & $=$ & 0.60 & square miles \\
Main-channel slope & $=$ & 976 & feet per mile \\
Surface-storage index & $=$ & 4.0 & percent \\
Total stream length & $=$ & 1.19 & miles \\
Population density (1990) & $=$ & 0.0 & persons per square mile \\
Impervious cover & $=$ & 0.0 & percent \\
Lake and swamp area & $=$ & 3.0 & percent \\
\hline
\end{tabular}


Table 2. Estimates of flood magnitudes for selected flood frequencies for Black Creek tributary at the culvert on New Jersey Route 94, milepost 43.0, Vemon Township, New Jersey

$[Q$, flood-magnitude estimates in cubic feet per second along with number indicating frequency of the recurrence interval in years; NJDEP SR, New Jersey Department of Environmental Protection Special Report]

Drainage area: 0.60 square miles

Latitude: $41^{\circ} 12^{\prime} 42^{\prime \prime}$

Longitude: $74^{\circ} 27^{\prime} 42^{\prime \prime}$

Highway: New Jersey Route 94

Milepost: 43.00

U.S. Geological Survey 7-1/2-minute quadrangle: Wawayanda, N.J.-N.Y.

\begin{tabular}{lllllll}
\hline Estimating method & Q2 & Q5 & Q10 & Q25 & Q50 & Q100 \\
\hline NJDEP SR 38 & 42 & 72 & 106 & 157 & 199 & 261 \\
\hline
\end{tabular}




\section{SELECTED REFERENCES}

Chow, V.T., Maidment, D.R., and Mays, L.W., 1988, Applied hydrology: New York, McGraw-Hill, 572 p.

Federal Emergency Management Agency, 1983, Flood insurance study for Vernon Township, Sussex County, New Jersey: Federal Emergency Management Agency, August 15, 1983: 14 p., 4 pls., 2 panels.

New Jersey Department of Environmental Protection, 1988, Technical manual for stream encroachment: New Jersey Department of Environmental Protection, Division of Water Resources, Bureau of Floodplain Management, 151 p., 6 app.

Stankowski, S.J., 1974, Magnitude and frequency of floods in New Jersey with effects of urbanization: New Jersey Department of Environmental Protection, Special Report 38, $46 \mathrm{p}$.

Thomas, D.M., 1964, Floods in New Jersey, magnitude and frequency: New Jersey Department of Conservation and Economic Development, Water Resources Circular 13, 145 p.

U.S. Soil Conservation Service, 1986, Urban hydrology for small watersheds: Engineering Division Technical Release 55, Washington, D.C., 162 p. 